\title{
ЭТИМОЛОГ ПРОФЕССОР, ДОКТОР ТУНЖЕР ГУЛЕНСОЙ
}

\section{Firdevs XISAMITDINOVA*}

Gölnaz YAGAFAROVA**

\begin{abstract}
Аннотация
Мәкәләлә күренекле төркиәтсе-ғалим Тунжер Гуленсойзың төрки телдәренең этимологияһы өлкәһенә бағышланған эшмәкәрлеге карала, этимология фәненең үсешендә уның роле баһалана.
\end{abstract} һүзлек.

Терәк Нүззәр: Төрки телдәре, Этимология, Тунжер Гуленсой, Этимологик

\section{BİR ETIMOLOG OLARAK PROF. DR. TUNCER GÜLENSOY Özet}

Bu makalede tanınmış Türkolog Tuncer Gülensoy'un Türk lehçelerinin köken bilimi ile ilgili çalışmaları ele alınmakta, âlimin etimoloji biliminin oluşumundaki rolü değerlendirilmektedir.

Anahtar Sözcükler: Türk Lehçeleri, Etimoloji, Tuncer Gülensoy, Etimoloji Sözlük.

\section{PROF. DR. TUNCER GULENSOY AS AN ETYMOLOGIST}

\begin{abstract}
In this article dedicated to the prominent Turkologist, researcher of the Turkic languages Tuncer Gulensoy, his activity in the field of the etymological analysis of the Turkic vocabulary is considered, his role in the formation of etymological science is traced. Dictionary.

Key Words: Turkic Languages, Etymology, Tuncer Gulensoy, Etymological

Тунжер Гуленсой - төрки телдәре донъяһында танылған шәхес. Тел кимәлдәренең кайhыһын ғына алып карама, уның хез̧мәттәрендә был өлкәләр берзәй ентеклелек, ихласлылык менән байкалған, тикшерелгән. Безгә айырыуса уның этимология өлкәһендәге хез̧мәттәре киммәтле һәм кызыклы.

Ғөмүмән, этимология мәсьәләләренә үзен тел ғилеме өлкәһендә әзерлекле тойған кеше генә тотона алалыр ул, сөнки был өлкә тикшеренеүсе алдына үтә лә яуаплы бурыстар куя.

Беренсенән, синхрон кимәлдә телдең лексик байлығын якшы белеү. Хатта белеү генә лә етмәй, бөтә нюанс һәм нескәлектәрендә, мәғәнәүи төс̧мөрзәренән башлап тарихи

\footnotetext{
* Prof. Dr., Rusya Bilimler Akademisi Ufa Tarih, Dil ve Edebiyat Enstitüsü, Ufa-BAŞKURDİSTAN/RUSYA, elmek: hisamitdinova@list.ru

(1D) ORCID ID: https://orcid.org/0000-0001-5997-9928

** Doç. Dr., Rusya Bilimler Akademisi Ufa Tarih, Dil ve Edebiyat Enstitüsü, Ufa-BAŞKURDİSTAN/RUSYA, elmek: rishrinat@mail.ru

(D) ORCID ID: https://orcid.org/0000-0003-4363-2940
} 
катламдарына тиклем ентекләп айырыу талап ителә. Тунжер Гуленсой иһә фәнни тикшеренеүзәрендә әзәби телдең йыйылған, апробация үткән, тейешенсә өйрәнелеп, һығымталар яһалған базаһы менән сикләнмәй (әзәби тел материалын грамматик йәһәттән төркөмләп, төрөк теленең грамматикаһы дәреслектәрен әзерләй ул 1985-1986, 1992, 1994 йылдарза). Уның хез̧мәттәренең тос өлөшөн төрки телдәренең, айырыуса төрөк теленең һөйләш һәм диалекттары мәсьәләләре алып тора. Ғалимдың ғилми эшмәкәрлеге менән якындан таныш булмаған кеше лә, уның нәшер ителгән хезुмәттәренә карап, Т. Гуленсойзың ерле һөйләш материалдарына ни тиклем зур баһа һәм әһәмиәт биреүен тос̧маллай ала. Ысынлап та, Анатолия һәм Румели һөйләштәре библиографияһы (1981), Кутахья һөйләштәре (1988), Тунджели һөйләштәре (1992), көнсығыш һәм көньяккөнсығыш Анатолия һөйләштәре (1993), Румели һөйләштәренең фонетикаһы (1993), Элазиг һөйләштәре (1994), төрөк теленең һөйләштәре (2003), Нахчиван һөйләштәре (2014) (Tuncer Gülensoy, 2018) кеүек хезुмәттәренең исемдәрен дә атап үтеү етә, ғалимдың диалектология өлкәһенә ни тиклем көс сарыф итеүен асык күреп була. Үз сиратында, диалектологик мәғлүмәттәр, билдәле булыуынса, - телдең тарихын өйрәнеүселәр өсөн бик мөһим сығанак, сөнки ерле тел материалдары күпселек осракта әзәби телдә теркәлмәгән йәки төшөп калыуға дусар булған тарихи мәғлүмәттәрзе һаклай, улар аша телдең үс̧еш этаптары тағы ла тәрәнерәк планда тергезелә. Т. Гуленсойзың этимологик тикшеренеүзәрендә бындай мәғлүмәттәр төп урындарзың береһен алып тора: ул төзөггн зур күләмле ике томлы этимологик һүзлектә һүззәрзең тамырзары асыкланғанда даими рәүештә Анатолия һөйләштәренән сағыштырма материал бирелә бара, шуның менән һүззең кулланылыу сиктәре һәм таралышы, шулай ук айырым тамырзарзың боронғо тамырз̧арға бәйләнеше асыклана. Мәсәлән, әзәби төрөк телендә кыпсак телдәренә хас булған maybıu hүззе юк, ул тик төрөк һөйләштәрендә шул ук мәғәнәлә tavuş, tauş, tavlştı формаларында, tavus et- 'өндәшеү' кылымы составында осрай (Gülensoy, 2011, cilt 2: 872). Бынан сығып, тауыш һүзенең төрөк теленә лә сит булмауы асыклана, төрки телдәрен берләштереүсе тағы ла бер дәлил табыла.

Икенсенән, тел тарихсыһынан телдең тарихын, үсеш этаптарын якшы күзаллай алыу талап ителә. Был йәһәттән дә мотлак телдең тарихын халык тарихына бәйләп, телдең тарихи үс̧еш этаптарын өйрәнеү кәрәклеге асык. Тимәк, этимолог телсе булыуз̧ан бигерәк тел тарихсыһы булырға тейеш. Сөнки ябай математик ысул менән генә теге йәки был һүззең ниндәй тамыр-нигезгг барып тоташканын аңлап та, аңлатып та булмай. Бының өсөн, кәм тигәндә, ошондай төр һүззектәрзең беренсел сығанактарын барлап, телдең тарихи үсееш дауамында уларзың урынын билдәләй белергә кәрәк. Т. Гуленсойзың османлы теле (1986), төрки тамғалар (1989), ис̧ке языузар һәм османлы теле дәрестәре (1994) буйынса бас̧тырылған хезुмәттәре лә ғалимдың иң тәүзə тел тарихына бәйле төшөнсәләрен теоретик планда нығытыуын күрһәтә. Артабан иһә Тунжер бей был күз̧әтеүзəрен "Doğu Anadolu Osmanlıcasi: Etimolojik sözlük denemesi” (1986), "Kürtçenin Etimolojik Sözlügü̈” (1994), "Türkiye Türkçesindeki Türkçe Sözcüklerin Köken Bilgisi Sözlüğü” (Анкара, 2007, 2011) хез̧мәттәрендә килтереп, тикшеренеүзәрен һүззəрззең беренсел тамырзарын билдәләүгә йүнәлтә. 2011 йылда нәшер ителгән ике томлы этимологик һүзлектә һәр бер һүз тәүге тамырына тиклем алып барып еткерелгән, тикшерелгән, тәүсығанак булған беренсел тамыр анык билдәләнгән (мәс̧әлән, sap hүзенең боронғо тамыры $s a$ күрһәтелә (Gülensoy, 2011, cilt 2: 732) йәки фараз рәүешендә 
икенсе төрлө аңлатма бирелә (мәсәлән, тауис һүзенең өнокшатыу һүзенә барып тоташыуын фаразлай (Gülensoy, 2011, cilt 2: 872).

Өсөнсөнән, этимология өлкәһендәге тикшеренеүзәр мотлак рәүештә бығаса аткарылған махсус этимологик тикшеренеүзәргә таянып башкарыла. Был йәһәттән Тунжер Гуленсойзың әсъәрзәрендә авторзың бик күп танылған этимологтарзың фекерзəренән хәбәрзар булыуын күрәбез. Тәү сиратта, әлбиттә, Төркиәлә нәшер ителгән этимологик хез̧мәттәр нигез̧ буларак файз̧аланыла. Андреас Титце (Tietze, 2002, cilt 1; Tietze, 2009, cilt 2), Хәсән Эрен (Eren, 1999), Севант Нишаньян (Nişanyan, 2012), Көзрәт Эмирулы (Emiroğlu, 1989) кеүек телселәрзең эштәренә таянып эш итә ғалим. Әлбиттә, төрки донъяһында күптән инде өлгөлө тип кабул ителгән һәм әһәмиәте бер вакытта ла кәмемәгән Дж. Клоссон (Clauson, 1972), А.М. Рясянен (Рясянен, 1969-1971), В.Э. Севортян (Севортян, 1974, 1978, 1980, 1989), В.Г. Егоров (Егоров, 1964), шулай ук Г. Рамстедт, У.Йохансон, Г. Дёрфер кеүек ғалимдарзың хезмәттәренә лә нигезләнә. Бының менән генә лә тукталып калмай ғалим, был әсәрзәрзәге кәмселектәрзе тотоп алып тәнкитләй, заман яңылыктарына һәм яңы тикшеренеүзәргә нигезुләнеп төзәтмәләр индерә, асыклап, аныклап китә. Мәс̧әлән, 2017 йылдың 13-16 ноябрендә Анкара калаһында “Яңы Төркиә стратегик тикшеренеүзәр үзәге" тарафынан ойошторолған “Төрки телдәрзə аралашкан өлкәләр королтайы”нда Төркиәлә нәшер ителгән дүрт этимологик һүззлектә (А. Титце, С. Нишаньян, Х. Эрен, К. Эмирулы) осраған хаталы караштарға бәйле ис̧кәрмәләр биреп, кайһы бер һүззәрззең этимологияһына кағылышлы үзенең фекерзəре менән уртаклашты. Катнашыусыларға таратылған күргәзмә материалдарында ла үрзә күрһәтелгән дүрт хезмәттә байтак һүззəрзең яңылыш бирелгәнлеген сағылдырған мәғлүмәттәр урын алған, улар хакында ентекле мәғлүмәтте ғалимдың ике томлык этимологик һүзлегендә табып була (мәсъәлән, tonton лексемаһы тураһында карағыз̧: (Gülensoy, 2011, cilt 2: 910). Әйткәндәй, Үз хезммәттәрен дә даими камиллаштырыу өс̧төндә эшләй ғалим.

Дүртенсенән, дөйөм ғилми кимәл, эрудиция, зирәклелек, күзәтеүсәнлек, откорлок кеүек шәхси сифаттар мөһимлеге мәғлүм. Тунжер бейзең был кешелек хосусиәттәре уны белгән һәр кемгә таныш, уның менән аралашып кына киткәндә лә был сифаттарына хайран калаһың. Оло быуын вәкилдәренә етди, тос уй-фекерзәрен еткерә, йәш быуын вәкилдәренә дәртләндереү, күтәремләү һүззәре табып, дәртләндереп-кеүәтләп ебәрә ул. Шул ук вакытта олпат, сал сәсле акыл эйәһе балаларса ябайлылык, саф күңеле менән арбай әңгәмәсеһен. Шуға күрә лә уға барыһы ла - олоһо ла, кесе лә - тартыла. Шуға күрә лә уның укыусылары байтак (уларын да ул яратып-һөйөп: “Был - минең улым (йәғни үз укыусыһы), был - ейәнем (йәғни укыусыһының укыусыһы)”, - тип мәрәкәләй. Улдары ла, ейәндәре лә, бүләләре лә уға шундай ук һокланыу катыш яратыу тойғоһо менән яуап кайтаралар). Укытыусы-укыусы тандемынан бына тигән байтак эш сыккан. Мәсәлән, Байбарс Гуленсой менән берлектә кейем-һалым һәм бизəнеүгә бәйле һүззәрзе теркәгән һүзлеге был тематик төркөмгә караған лексемаларзың этимологияһын һәм мәғәнәһен асыклай, тотош бер лексик-семантик төркөмгә тарихи-семантик анализ яһай (Gülensoy, 2000). Уның укыусылары үззәре инде күптәргә канат куйған, фәндә үз урындарын табып, ышаныслы азымдар менән атлай. Тунжер бейзең укыусылары Әхмәт Буран, Эржан Алкая мөхәррирлегендә әз̧ерләнеп бас̧тырылған TÜRKLAD журналы ла быға асык мис̧ал. Быны күреп: "Бына ул фәндә күсәгилешлелек, бына ул ғилемдең яңы сифатта килеүе, яңы бас̧кыска күтәрелеүе”, - тип ирекһеззəн уйлап куяһың. Ә остаз һаман да шул Остаз 
булып кала, юл күрһәтә, белмәгәндә, әйтеп ебәрә, төзәтә, дөрөс̧ләй, кәңәш бирә, хәкикәтте эзुләргә ярзам итә... Сөнки ул - Шәхес, киң карашлы Укытыусы, хәкикәт өсөн Көрәшсе, тәрән белемле Телсе.

Төрки тел ғилемендә этимологик тикшеренеүзәр өлкәһендә һуңғы арала бик зур Үзгәрештәр һәм алға китеш күзәтелде. Асылда бер быуат эсендә байтак төрки телдәренең Үз этимологияһы фәне булдырылды, быны без уларзың нәшер ителгән этимологик һүзлектәренән күрә алабыз. Дөйөм төрки телдәр өсөн уртак булған “Древнетюркский словарь” (Л., 1969), В.Э. Севортяндың күп томлы һүззлегенән тыш күпселек төрки телдәрендә этимология буйынса лексикографик хез̧мәттәр нәшер ителде: сыуаш, якут, татар, каззак, тыва, кырғыз һ.б. телдәрзә, әлбиттә, төрөк теле буйынса хәзерге көндә махсус этимологик хез̧мәттәр билдәле. һәм, әйтергә кәрәк, һәр һүзлек үз теленең тарихи нигеззəрен генә тикшереп калмай, hәр хезмәт дөйөм төркиәткә тос өлөшөн индерә. Ә инде Рәсәй фәндәр академияһының Тел ғилеме институты ғалимдары тарафынан әзерләнгән “Сравнительно-историческая грамматика тюркских языков” томдары (Сравнительно-историческая грамматика тюркских языков, 2001, 2006) менән бигерәк тә “Алтай телдәренең этимологик һүзлеге" (Etymological dictionary of the Altaic languages, 2003), А.В. Дыбоның хезмәттәре - төрки телдәренең этимологияһы өсөн баһалап бөтөргөһөз сығанак һәм ышаныслы нигез ул. Был мәғлүмәттәргә нигезләнеп, һис шикһез, hәр бер төрки теле вәкилдәре үз телдәренең этимологияларын тулы рәүештә булдыра ала. Әйтергә кәрәк, замана елдәре этимологияны ла урап үтмәй. Тупланған мәғлүмәттәр махсус электрон базаларға теркәлә бара, информацион арауыкта, донъя селтәрендә Үз урынын ала. Мәсъәлән, Рәсәй төркиәтселәре тарафынан “Төрки телдәренең тулы электрон этимологик мәғлүмәттәр базаһы” (Turcet.dbf) әзерләнә, ул этимологияға бәйле төрлө мәсьәләләрзе хәл итергә ярзам итә, атап әйткәндә, семантик реконструкция, һүзьяһалыш типтарының реконструкцияһы, тәүтел лексемаларының ареалдарын билдәләү кеүек проблемаларзы асыклауға йүнәлтелә. Хатта, проекттың етәкселәре хәбәр итеүенсә, “был базаның нигезендә айырым төрки телдәренең этимологик һүзлектәрен автоматик рәүештә төзөү мөмкинселеге лә буласак” (http://iling-ran.ru/official/20122014_oifn_langlit_report_2013.pdf). Шуны ла һызык өсътөнә алып үтеү мөһим: бындай база төрки телдәре өсөн дә, донъя телдәренең башка төркөмдәре өсөн дә әлегә иң беренсе тәжрибә, аналогтары әлегә булдырылмаған.

һуңғы йылдарза башкорт тел ғилеме өсөн дә был мәсьәлә көнүзәк мәсьәләләрзең береһе буларак күтәрелде. Рәсәй фәндәр академияһының Өфө федераль тикшеренеү Үзәгенең Тарих, тел һәм әзәбиәт институты хез̧мәткәрзәре тарафынан Ф.Ғ. Хисамитдинова мөхәррирлегендә 2011-2018 йылдарза нәшер ителгән 10 томлык аңлатмалы-тәржемәүи (әйткәндәй, был һүзлектә баш hүззљр рус, инглиз һәм төрөк телдәренә аузарылып бирелә) һүзлек проекты тамамланғандан һуң тел ғилеме бүлеге хез̧мәткәрзәре ошо яңы зур проектка - башкорт теленең этимологик һүззлеген төзөүгә тотонорға карар итте. Был тәбиғи зə, сөнки икһезु-сикһез лексик байлык хазинаһын синхрон планда байкап сыккандан һуң ошо hүз хазинаһының нигеззәрен асыклау ихтыяжы кағизə рәүешендә барлыкка килә. Этимологик, йәғни һүззәрзең, тимәк, телдең тарихы һүзлеген төзөө талабын тулы кимәлдә бойомға ашырыу максатында тәү сиратта төрки телдәр материалында төзөлгән лексикографик хезмәттәр менән танышыу бурысы куйыла. Ошо әзерлек этабында, әлбиттә, без зə Тунжер Гуленсой тарафынан төзөлөп нәшер ителгән ике томлык этимологик һүзлегенә мөрәжәғәт иттек, ғалимдың 
караштарын өйрәндек, һүззлектең төзөлөш принциптарына иғтибар иттек, һәм, иң мөһиме, был хезмәт буйынса төрөк тел ғилеменең этимология өлкәһендәге һуңғы казаныштары менән таныштык.

һүзлеккә килгәндә, уның тәү сиратта үзенсәлекле королошо иғтибарзы йәлеп итә. Билдәле булыуынса, этимологик һүззектәр бер нисә төр булырға мөмкин. Берәүзәре этимологик һүззлеккә морфологик йәки һүзьяһалыш анализын карата, икенселәре тамыр һүззәрзе асыклаузы максат итеп куя, өсөнсөләре тамыр һүззәрзең тарихын барлаузы хуп күрә. Был һүзлектә иһә ошо өс төр һүзлектең һәммәһе лә сағылыш тапкан. һүзлектә баш hүз рәүешендә бирелгән һүзгә тулы һүзьяһалыш анализы эшләнә, уның дериваттары бирелә, башка төрки телдәренән аналогтар килтерелә, төрөк теленең һөйләштәренән материалдар бирелә, төрлө телселәрзең был һүззең килеп сығышына бәйле караштары килтерелә, ғалимдың улар менән килешмәгән осрактары күрһәтелеп, үз фараздары ла урын ала. Ошо рәүешле әзерләнгән һүзлек, әлбиттә, төркиәттә лайыклы урынын таба.

Шулай итеп, ғалим был һүззлеге менән төрки телдәренең этимологияһы фәненә тос өлөш индерә, төрки телдәрзән береһенең вәкиле буларак, Үз телен һәм уның диалекттарын бик тәрән белгән тикшеренеүсе буларак, яңы караштар, яңы ис̧батлаузар менән этимология фәнен байыта, бөгөнгө көндә йәшәп килгән яңылыш фекерзәргә, хаталы караштарға төзəтмәләр индерә, фәнгә һәм дөрөс̧лөккә хилаф килмәһен тигән төп ғилми канунға тоғро кала, шуға хез̧мәт итә. һәм был юлда Үз хез̧мәттәренә өс̧тәлмәләр, дөрөс̧ләмәләр индереүзән дә баш тартмай - ысын ғалим ғына хаталар өс̧төндә эш алып барып, йәмәғәтселек иғтибарына тартынмай тәкдим итә ала. Шул яғы менән, йәғни ихласлығы, яңылыкка һәр вакыт асык булыуы, Үз хаталарын таный белеүе, башкалар иғтибарына тәкдим иткәндә үззенә генә хас юмор һәм үзенә йүнәлтелгән ирония менән Тунжер бей айырыуса һокландыра, ис̧тә кала. Фәндең фән булып үс̧ешеүе, замана менән йәнәш атлай алыуы ошондай шәхестәр аркаһында барыуы сер түгел. Без зə, башкорт коллегалары һәм укыусылары исеменән Тунжер бейзе якынлашып килгән күркәм юбилейы менән ихлас котлайбыз, киләсәктә Ағизелдәй озон ғүмер, Урал тауындай ныклы һаулык, Кош юлындай серле һәм мөғжизәле фән юлында яңынан-яңы сағыу асыштар теләйбез!

\section{Әзәбиәт}

CLAUSON, G. (1972). An Etymological Dictionary of Pre-Thirteen Century Turkish, Oxford University Press.

DOERFER, G. (1971). Gedanken zur Gestaltung cines idealen Türk-ischen Etymologischen Wörterbuchs. Orientalistische Literaturzeitung. LXVI. № 9/10. Sp. 437-454.

EREN, H. (1999). Türk Dilnin Etimolojik Sözlüğü. Ankara.

STAROSTIN, S.A., DYBO, A.V., MUDRAK, O. A.. (with the assistance of I. Gruntov and V. Glumov) (2003). An Etymological Dictionary of the Altaic languages. Leiden, Brill, 2003.

GÜLENSOY, B., GÜLENSOY, T. (2000). Türkiye Giyim-Kuşam ve Süslenme Sözlüğü - etimolojik ve açılklamalı. İstanbul: Motif vakfı yayınları. 
GÜLENSOY, T. (2011). Türkiye Türkçesindeki Türkçe Sözcüklerin Köken Bilgisi Sözlüğü. Ankara. 2 cilt.

EMIROĞLU, K. (1989). Trabzon-Maçka Etimoloji Sözlüğü. Gülsen ofset.

NIŞANYAN, S. (2012). Sözlerin Soyağacı Çağdaş Türkçenin Etimolojik Sözlüğü, Everest Yayıncilık.

TIETZE, A. (2002). Tarihi ve Etimolojik Türkiye Türkçesi Lugatı (A-E), İstanbul, Simurg Kitabevi, cilt 1; TIETZE, A. (2009). Tarihi ve Etimolojik Türkiye Türkçesi Lugatı (F-J), İstanbul, VÖAW (Avusturya Bilimler Akademisi Yayınları), cilt 2.

TUNCER GÜLENSOY (2018, 4 May1s). Erişim adresi: http://www.biyografya.com/biyografi/5362

Древнетюркский словарь / Ред. В.М.Наделяев, Д.М.Насилов, Э.Р.Тенишев, А.М.Щербак. - Л.: Наука, 1969. - 676 с.

ДЫБО, А.В. (2013). Этимологический словарь тюркских языков. Том 9 (дополнительный): Этимологический словарь базисной лексики тюркских языков. Астана.

ЕГОРОВ, В.Г. (1964). Этимологический словарь чувашского языка. Чебоксары.

Программа фундаментальных исследований Секции языка и литературы ОИФН РАН «Язык и литература в контексте культурной динамики»: Отчеты по проектам за 2013 год // http://iling-ran.ru/official/2012-2014_oifn_langlit_report_2013.pdf

РЯСЯНЕН, М. (1969-1971). Versuch eines etymologischen Wörterbuchs der Türksprachen, Helsinki, t. I-II.

СЕВОРТЯН, Э.В. Этимологический словарь тюркских языков. М.: Наука. Т.1 (Общетюркские и межтюркские основы на гласные). 1974. - 767 с.; Т.2 (Общетюркские и межтюркские основы на букву “Б”). 1978. - 349 с.; Т.3 (Общетюркские и межтюркские основы на буквы “В”, “Г” и “Д”). 1980. - 395 с.; Т.4 (Общетюркские и межтюркские основы на буквы “Ж”, “Ж”, “Й”). 1989. - 292 с.

Сравнительно-историческая грамматика тюркских языков. Лексика: 2-е изд., доп. / Авторы: Э.Р.Тенишев, Г.Ф.Благова, И.Г.Добродомов, А.В.Дыбо, И.В.Кормушин, Л.С.Левитская, О.А.Мудрак, К.М.Мусаев; отв.ред. Э.Р.Тенишев. - М.: Наука, 2001. $822 \mathrm{c}$.

Сравнительно-историческая грамматика тюркских языков. Пратюркский языкоснова. Картина мира пратюрка. М., Наука. 2006. Отв.ред. Тенишев Э.Р.

Этимологический словарь якутского языка: Саха тылын этимологичаскай тылдьыта. АДь. А-Дь. Часть 1. 1 чааха / Гавриил Васильевич Попов. - Новосибирск: Наука, 2003. $178 \mathrm{c}$. 